\title{
Effects of intraruminal sodium chloride infusion on rumen and renal nitrogen and electrolyte dynamics in sheep
}

\author{
BY IAN R. GODWIN AND VERNON J. WILLIAMS \\ Department of Physiology, University of New England, Armidale, NSW 2351, Australia
}

(Received 19 March 1986 - Accepted 3 April 1986)

\begin{abstract}
1. Sheep were given $800 \mathrm{~g}$ low-protein roughage/d at $2 \mathrm{~h}$ intervals and infused intraruminally with $0,500,750$, $1000,1250,1500$ or $2000 \mathrm{mmol}$ sodium chloride/d in $436 \mathrm{ml}$ water. The digestibility of various food fractions and rumen ammonia, volatile fatty acids (VFA) and liquid turnover rate were measured, along with renal haemodynamics and the renal excretory patterns of nitrogen and electrolytes. $A d$ lib. food intake was determined during the infusion of 0 and $2000 \mathrm{mmol} \mathrm{NaCl} / \mathrm{d}$.

2. Infusion of $\mathrm{NaCl}$ up to $750 \mathrm{mmol} / \mathrm{d}$ had virtually no effect on the indices measured, except water intake and water excretion. Infusion of greater amounts caused a step-wise decrease in the digestibility of organic matter $(\mathrm{OM})$ and $\mathrm{N}$. Rumen liquid turnover rate was increased substantially and rumen $\mathrm{NH}_{3}$ and VFA concentrations were decreased. Ad lib. food intake was not different when either 0 or $2000 \mathrm{mmol} \mathrm{NaCl} / \mathrm{d}$ were infused into the rumen.

3. The glomerular filtration rate and effective renal plasma flow (ERPF) were substantially increased after the infusion of $1250 \mathrm{mmol}$ or more $\mathrm{NaCl} / \mathrm{d}$. Extracellular fluid volume was also increased. The renal excretion of urea and uric acid + allantoin (URAL) were decreased at the higher infusion rates but the fractional excretions of both these substances were enhanced. The excretion of sodium, chloride, calcium and magnesium were markedly increased with increasing salt infusion.

4. The results suggest that high $\mathrm{NaCl}$ inputs into the rumen increase the rumen turnover rate, which in turn decreases the digestibility of OM, particularly $\mathrm{N}$. This causes lower rumen $\mathrm{NH}_{3}$ and VFA concentrations. Plasma urea and URAL concentrations are also decreased and this causes lower renal excretion of these substances despite a much higher fractional excretion resulting from the greatly enhanced urine flow rate.

5. When roughages low in $\mathrm{N}$ are given, $\mathrm{NaCl}$ intake should be kept below $20 \mathrm{mmol} / \mathrm{kg}$ body-weight per $\mathrm{d}$ to prevent a decline in the digestibility of the food and any consequent reduction in protein available to the sheep.
\end{abstract}

In many areas of the world sheep consume plants or drinking water which have a high sodium chloride content. For example, Wilson (1966a) found that sheep grazing Atriplex spp. as a major food constituent had salt intakes as high as $4217 \mathrm{mmol} / \mathrm{d}$.

Some effects of high $\mathrm{NaCl}$ intakes on food utilization have been determined. Croom et al. (1982) noted that the addition of $50 \mathrm{~g} \mathrm{NaCl} / \mathrm{kg}$ to high-grain diets increased the efficiency of organic matter (OM) utilization in steers. Hemsley et al. (1975) added $1366 \mathrm{mmol} \mathrm{NaCl} / \mathrm{d}$ to a linseed-meal diet and $171 \mathrm{mmol} / 1$ to the drinking water of sheep and showed that this treatment reduced rumen $O M$ digestion by $24 \%$ and rumen protein digestion by $10 \%$. Further, Hemsley (1975) found that similar treatment produced a substantial increase in wool growth.

The recycling of plasma urea to the rumen has been extensively studied. It returns to the rumen directly across the rumen epithelium (Houpt \& Houpt, 1968) and also via saliva (Somers, 1961). In animals given low-protein or high-energy diets, or both, returned urea helps maintain rumen ammonia above a concentration which limits microbial protein synthesis (Bondi, 1981).

The level of urea in the plasma is a major determinant of the amount of nitrogen recycled to the reticulo-rumen. The plasma level may be affected by $\mathrm{NaCl}$ intake, as sheep loaded with urea and infused intraruminally with $\mathrm{NaCl}$ showed an increased renal excretion and a consequent lowering of the plasma concentration of urea compared with animals not given $\mathrm{NaCl}$ (Godwin \& Williams, 1984).

A decrease in urea recycling and a decrease in rumen turnover time should reduce the 
digestion of low-protein roughages in the rumen. The present study examines the effects of high levels of $\mathrm{NaCl}$ on the digestibility of food and the dynamics of the rumen and kidneys of sheep given a low-protein roughage.

A summary of part of this work has been published (Godwin \& Williams, 1983).

\section{MATERIALS AND METHODS}

Animals, method of feeding and diet

Twelve merino ewes, aged $2-4$ years, and weighing $39 \cdot 8 \pm 1 \cdot 0 \mathrm{~kg}$ body-weight were dosed with anthelmintic (Ranide; Merck, Sharpe \& Dohme), fitted with a rumen cannula under surgical anaesthesia and individually housed in metabolism cages. They were given the experimental diet for at least 1 month before any experimental treatment was imposed.

The treatment group of eight animals was fed automatically (Nicol \& Corbett, 1971) with one-twelfth of their daily ration at $2 \mathrm{~h}$ intervals.

The four control sheep (not infused with $\mathrm{NaCl}$ ) were fed once daily at 12.00 hours to determine whether there was any consistent change in food intake or apparent digestibility during the experimental periods.

Food consisted of $96 \mathrm{~g}$ lucerne (Medicago sativa) chaff plus $704 \mathrm{~g}$ oaten chaff, with a moisture content of approximately $100 \mathrm{~g} / \mathrm{kg}$. The daily food supply had a gross energy value of approximately $16.9 \mathrm{MJ}$ and contained approximately $6.8 \mathrm{~g} \mathrm{~N}, 127$ mmol sodium, $112 \mathrm{mmol}$ potassium, $86 \mathrm{mmol}$ calcium, $55 \mathrm{mmol}$ magnesium and $30 \mathrm{mmol}$ phosphorus. All animals were dosed weekly with $7500 \mu \mathrm{g}$ vitamin $\mathrm{A}$ and $125 \mu \mathrm{g}$ vitamin $\mathrm{D}_{3}$ (Vetemul; ICI).

\section{Experimental procedures}

Experimental group. The animals were infused intraruminally with salt solutions containing $0,500,750,1000,1250,1500$ or $2000 \mathrm{mmol} \mathrm{NaCl} / \mathrm{d}$ in $436 \mathrm{ml}$ water. Infusions were in this order for all sheep to reduce adaptation periods to the higher salt levels. Infused salt was considered as dietary for digestibility measurements.

Following a 9 d equilibration on each salt solution one jugular vein $(1.5 \mathrm{~mm}$ OD, medical grade polyvinyl tubing; Dural Plastics), and the bladder (Folatex Balloon Paediatric Catheter $8 \mathrm{Ch}$; Euro-Medical Industries, Sussex) were catheterized. The jugular catheter was flushed daily with approximately $10 \mathrm{ml}$ heparinized saline $(9 \mathrm{~g} \mathrm{NaCl} / \mathrm{l})$. The following morning a $3 \mathrm{~d}$ urine collection was commenced. At the end of this urine collection an intravenous infusion of $0.5 \mathrm{ml} / \mathrm{min}$ of a solution containing $(\mathrm{g} / \mathrm{l}) 100$ inulin, $50 p$-amino hippurate (PAH) and $8 \mathrm{NaCl}$ was commenced at 12.00 hours; blood samples were obtained from the contralateral jugular vein by needle puncture at $14.00,16.00$ and 18.00 hours and urine collected over the same period. Glomerular filtration rate (GFR) and effective renal plasma flow (ERPF) were calculated from inulin and $\mathrm{PAH}$ clearances respectively over this $4 \mathrm{~h}$ period. The correction of Rabinowitz et al. (1971) for plasma protein binding of PAH was used. The day following GFR and ERPF measurements, extracellular fluid volume (ECF) was estimated by injecting $20 \mathrm{ml}$ inulin solution $(200 \mathrm{~g} / \mathrm{l})$ intravenously and sampling blood from the contralateral vein at $3,7,20,35,50,65,80$ and 100 min following injection. Calculation of ECF was according to the method of Poulsen et al. (1977).

Rumen fluid volume and outflow rate were measured on the same day as ECF by injecting $200 \mathrm{ml}$ of a solution containing $1.108 \mathrm{~g}$ chromium as CrEDTA into the rumen and serially sampling rumen contents for $36 \mathrm{~h}$. Calculations were by the formulae presented by Faichney (1975).

Following the previously described procedures, digestibility of the food was measured over a $10 \mathrm{~d}$ period. Daily faecal samples were dried at $95^{\circ}$ for $4 \mathrm{~d}$ and pooled for each animal for later analysis. 
Because substantial differences were noted in the digestibility of food and the rumen turnover rate when the animals were given the lowest and highest salt infusions, ad lib. food intake was measured at these two infusion levels. This study was made following the end of the collection period for the $2000 \mathrm{mmol} \mathrm{NaCl} / \mathrm{d}$ infusion. Four of the animals were maintained on an infusion of $2000 \mathrm{mmol} \mathrm{NaCl} / \mathrm{d}$ whilst the other four were infused with water only for $13 \mathrm{~d}$. The diet, $120 \mathrm{~g}$ lucerne chaff plus $880 \mathrm{~g}$ oaten chaff $/ \mathrm{kg}$, was fed ad lib. during this period. Digestibility and food intake were determined over the following $10 \mathrm{~d}$. The four animals that were infused with salt were then given water and vice versa. This salt infusion commenced at $500 \mathrm{mmol} / \mathrm{d}$ and increased to $2000 \mathrm{mmol} / \mathrm{d}$ over the next $10 \mathrm{~d}$. These infusions were maintained over the next $20 \mathrm{~d}$ with measurements taken during the last $10 \mathrm{~d}$. Samples of rumen fluid were collected at approximately 21.00 hours on the first and last day of these collection periods for determination of rumen indices.

Control group. During the time the experimental groups were given $800 \mathrm{~g}$ roughage/d, the control animals were given the same amount of food and any refusals were weighed and recorded. Digestibility of the ration was measured six times at about six-weekly intervals. Food was offered ad lib. during the same period as the experimental group. Intake and digestibility of food were also determined during this treatment. Samples of rumen fluid were taken at about 21.00 hours on the first and last day of each digestibility trial.

Analytical. Plasma and urine $\mathrm{Mg}$, inorganic $\mathrm{P}\left(\mathrm{P}_{\mathrm{i}}\right), \mathrm{Ca}$, glucose, urea, uric acid + allantoin (URAL), creatinine and plasma protein were measured with a Cobas-Bio centrifugal analyser (Hoffman-La Roche, Switzerland). Pierce Kits (Pierce Chemical Co. Illinois) were used for $\mathrm{Mg}$ and $\mathrm{P}_{\mathrm{i}}$ and Hoffman-La Roche kits for the remainder. $\mathrm{Na}$ and $\mathrm{K}$ were determined by flame photometry (EEL 227; Evans Electroselenium, Essex) and $\mathrm{Cl}$ was measured using a CMT 10 chloride titrator (Radiometer, Copenhagen). Inulin and PAH were determined by the methods of Bacon \& Bell (1948) and Smith et al. (1945).

Faeces, food and urine were digested by the method of Cresser \& Parsons (1979). Total $\mathrm{N}$ was estimated in the digest by steam distillation and titration and $\mathrm{Na}, \mathrm{K}$ and $\mathrm{Mg}$ by atomic absorption spectrophotometry (SB 900; GBC Scientific Equipment, Melbourne). $\mathrm{Ca}$ and $\mathrm{P}_{\mathrm{i}}$ were determined as for plasma.

$\mathrm{NH}_{3}$ concentration was measured in rumen fluid, after protein precipitation with ethanol, and also in urine, by distillation and titration. Urine urea and URAL values were corrected for $\mathrm{NH}_{3}$ content from this value. Rumen total VFA was also determined by distillation of the supernatant fraction from centrifuged rumen contents and subsequent titration.

Osmolality of rumen fluid and urine was measured by freezing-point depression (Fiske Associates, Connecticut), $\mathrm{Cr}$ was determined in rumen fluid and in urine by atomic absorption spectrophotometry and packed cell volume (PCV) was estimated by a micromethod (Hawksley and Sons, Sussex). Organic matter of food and faeces was obtained by ashing for $2 \mathrm{~h}$ at $400^{\circ}$ followed by $12 \mathrm{~h}$ at $600^{\circ}$ and the energy contents of food and faeces were estimated by ballistic bomb calorimetry (Ser 330; Gallenkamp, Sussex). pH of urine and rumen fluid was measured with a glass electrode (Radiometer).

\section{RESULTS}

\section{Control animals}

Appetite. The animals when given $800 \mathrm{~g} / \mathrm{d}$ showed no decline in food intake and refusals were rare throughout the experiment.

Apparent digestibility. There was little change in digestibility. The values for energy increased slightly after the first 6 weeks and then remained at this level (Table 1).

Ad lib. values. Ad lib. food intakes, digestibility of the various fractions measured and rumen fluid values are shown in Table 1 . Ad lib. food intake by all sheep was greater than $800 \mathrm{~g}$, the amount fed during the previous periods; the mean increase was $14 \%$. 


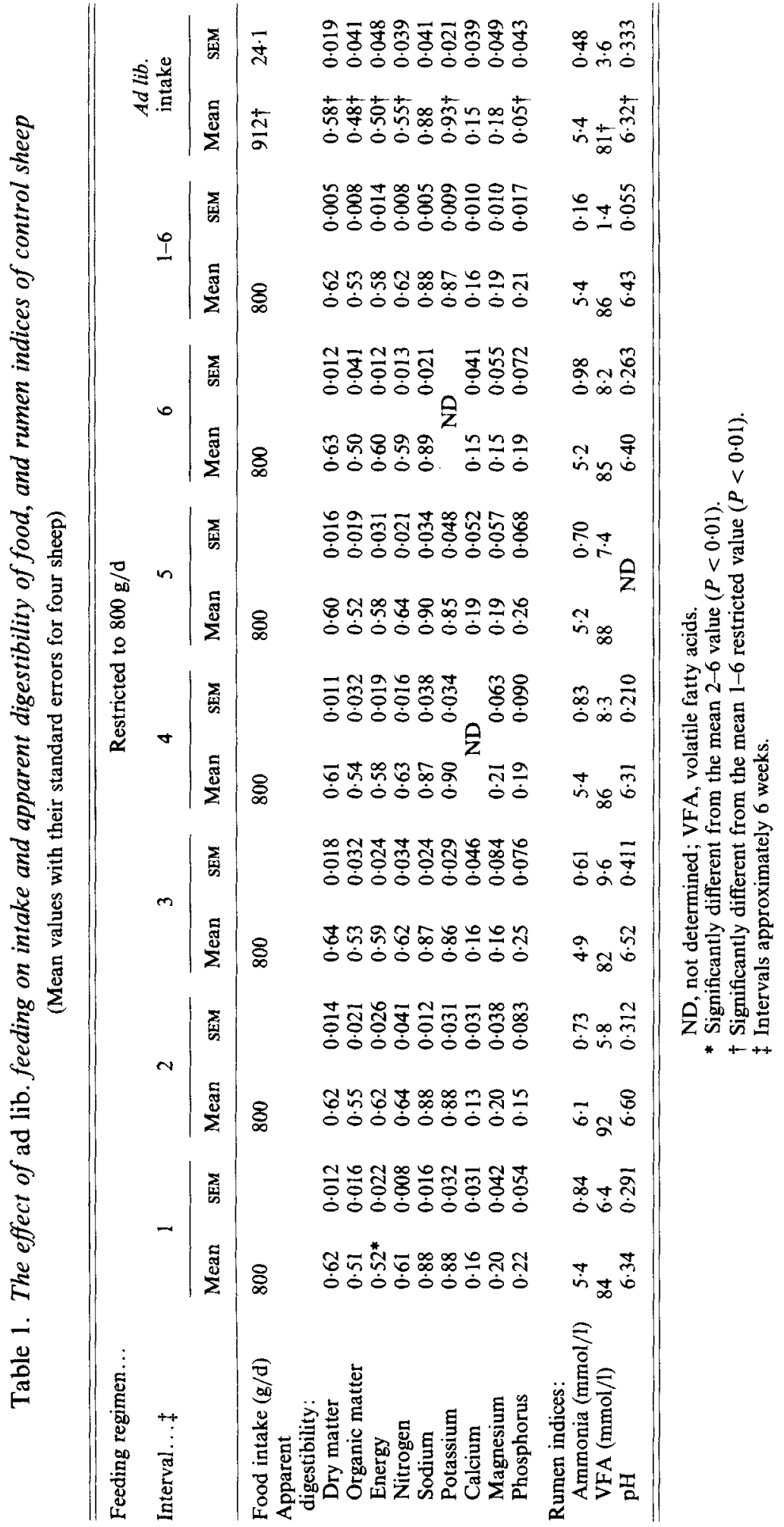


The digestibility of all organic components and $\mathrm{P}$ was decreased with ad lib. feeding. However, values for $\mathrm{Ca}, \mathrm{Mg}$ and $\mathrm{Na}$ were unaltered whilst the value for $\mathrm{K}$ was slightly increased. Rumen $\mathrm{NH}_{3}$ was the same for both feeding levels but rumen VFA and $\mathrm{pH}$ were decreased with ad lib. feeding.

\section{Experimental animals}

Rumen fluid dynamics. Increasing salt infusions increased rumen fluid volume only slightly (from $5 \cdot 1$ to $5 \cdot 5$ litres) but rumen liquid outflow was markedly affected, rising from 3.42 to 8.12 litres/d with $0-2000 \mathrm{mmol} \mathrm{NaCl}$ infusion (Table 2). Analysis of urine for $\mathrm{Cr}$ indicated that a maximum of $3.6 \%$ was absorbed, which is considered of negligible importance.

Apparent digestibility. The digestibility of dry matter, OM, energy and $\mathrm{N}$ are shown in Table 3. No significant changes occurred in these values until $1000 \mathrm{mmol} \mathrm{NaCl} / \mathrm{d}$ was infused. Each constituent then showed a linear decrement with additional salt. The apparent digestibility of the electrolytes measured are also shown in Table 3.

The digestibility of $\mathrm{Na}$ increased following the infusion of $500 \mathrm{mmol} \mathrm{NaCl} / \mathrm{d}$ and remained at this level for the remaining infusates. $\mathrm{K}$ digestibility was significantly increased above the basal level with the infusion of $500 \mathrm{mmol} \mathrm{NaCl} / \mathrm{d}$, which was probably fortuitous as higher infusion rates had no effect. The digestibility of $\mathrm{Ca}$ increased with salt infusion until $1000 \mathrm{mmol} / \mathrm{d}$ were infused; thereafter it decreased slightly, but not to the pre-infusion value. $\mathrm{Mg}$ and $\mathrm{P}$ values were unchanged.

Rumen fluid constituents (Table 2). Rumen pH slightly increased from 6.35 to 6.83 with increasing salt infusion. No change occurred in rumen osmolality until $1000 \mathrm{mmol} \mathrm{NaCl} / \mathrm{d}$ were infused; it then increased linearly with infusion rate. There was no effect on rumen $\mathrm{NH}_{3}$ concentration until $1000 \mathrm{mmol} \mathrm{NaCl} / \mathrm{d}$ were infused, then the values declined. Total VFA concentration followed a similar pattern to that of rumen $\mathrm{NH}_{3}$, although the response was much more attenuated.

Plasma and renal $N$ dynamics (Table 4). Urine flow rate increased linearly from 0.42 to $4.07 \mathrm{ml} / \mathrm{min}$ with the infusion of salt from 0 to $2000 \mathrm{mmol} / \mathrm{d}$. GFR values were calculated from the renal clearances of both inulin and creatinine which correlated well $\left(y=1.18 x-7.68, r^{2} 0.96\right.$, where $x$ is creatinine and $y$ is inulin). The results presented are creatinine values. GFR showed no change until $1000 \mathrm{mmol} \mathrm{NaCl} / \mathrm{d}$ were infused and it then increased in a curvilinear manner from $55 \cdot 2$ to $67 \cdot 1 \mathrm{ml} / \mathrm{min}$ at $2000 \mathrm{mmol} \mathrm{NaCl} / \mathrm{d}$. ERPF increased linearly with the quantity of salt infused. Filtration fraction (FF), determined as the ratio, GFR :ERPF, was unaltered by the treatments. PCV remained relatively constant throughout the experiment.

Plasma urea level remained relatively constant at about $4 \mathrm{mmol} / 1$ until $1000 \mathrm{mmol}$ $\mathrm{NaCl} / \mathrm{d}$ were infused, when a large decrease to $1.7 \mathrm{mmol} / 1$ occurred. Increased salt infusions caused further slight decreases in the plasma level to $0.8 \mathrm{mmol} / 1$ with the maximum salt infusion.

Urea excretion was increased by the infusion of up to $750 \mathrm{mmol} \mathrm{NaCl} / \mathrm{d}$, but further salt input resulted in a decrease in excretion to below the pre-infusion value. Increasing salt infusion from 1250 to $2000 \mathrm{mmol} / \mathrm{d}$ caused no significant change in urea excretion. However, the fractional urea clearance (clearance of urea/GFR) increased with increasing salt infusion.

Plasma URAL showed no change until $1000 \mathrm{mmol} \mathrm{NaCl} / \mathrm{d}$ were infused and thereafter it fell with increasing salt input. The plasma concentrations were all very low. The excretion of URAL showed a continual decline with increased salt input. However the fractional excretion of URAL increased with increasing salt intake after $750 \mathrm{mmol} \mathrm{NaCl} / \mathrm{d}$ were infused. The values obtained with this level and subsequent levels of infusate were all greater than $100 \%$, indicating substantial tubular secretion of URAL. 


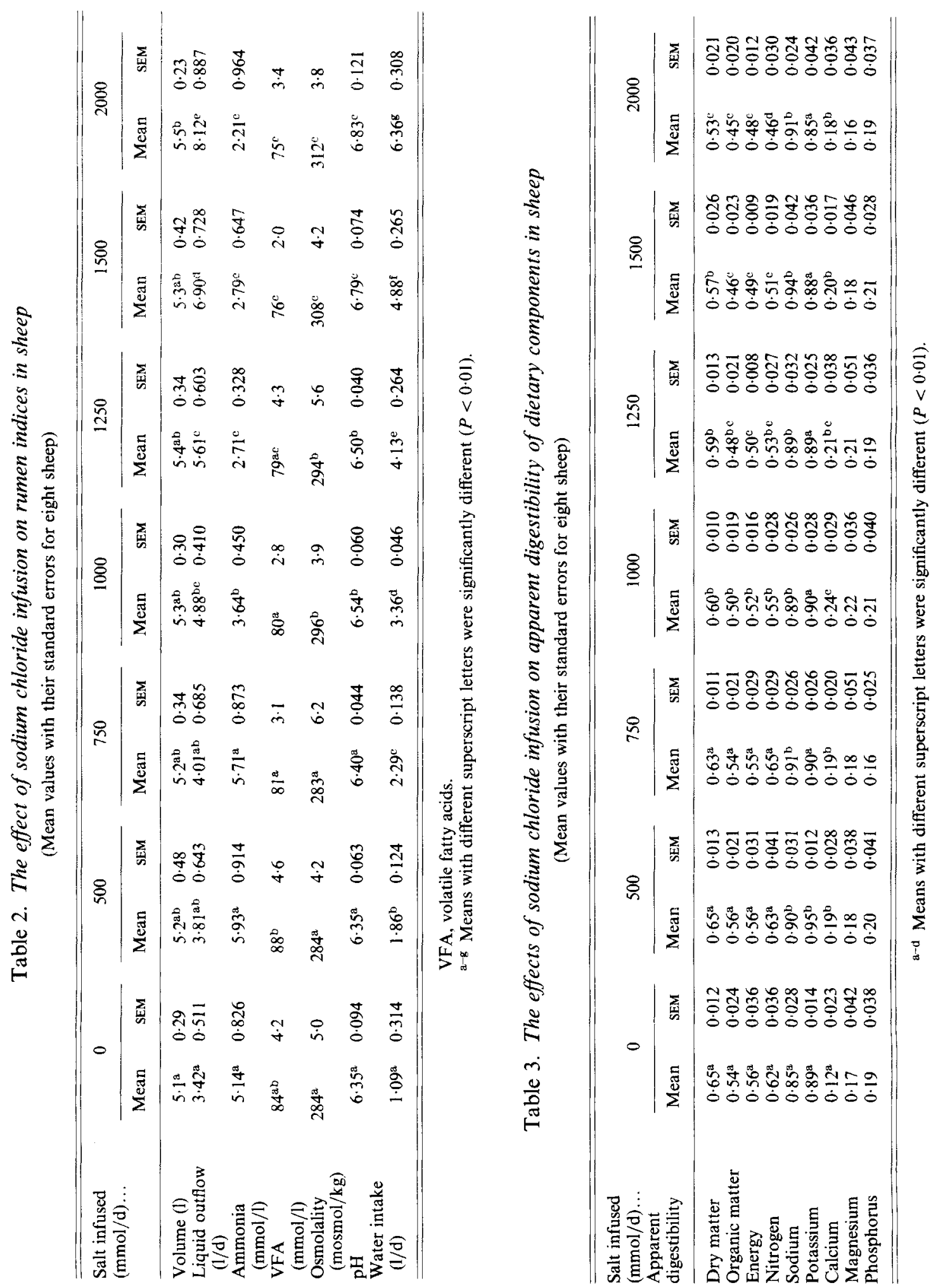




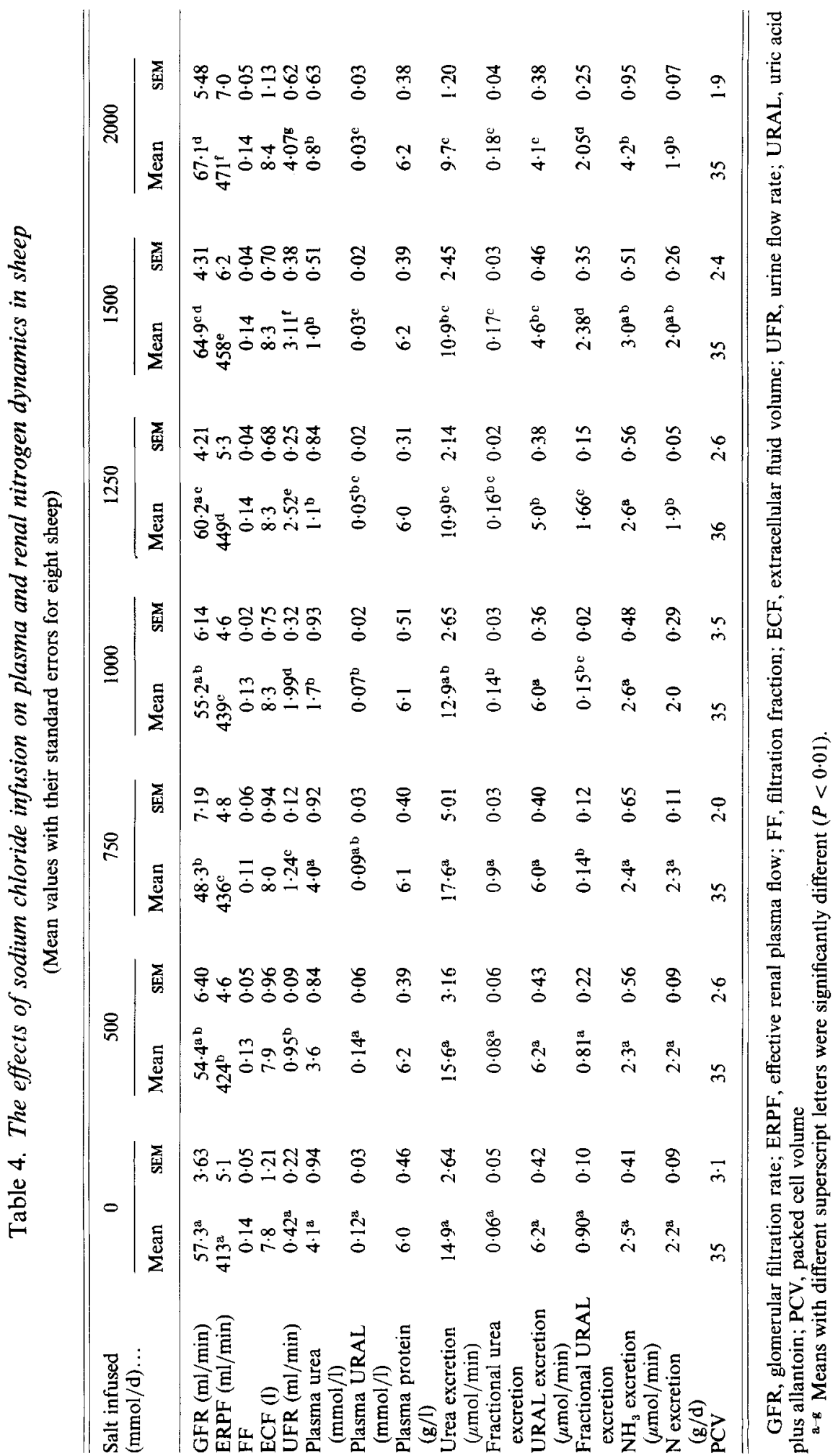


§్

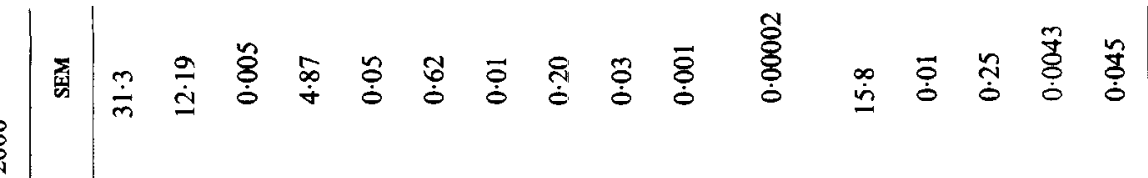

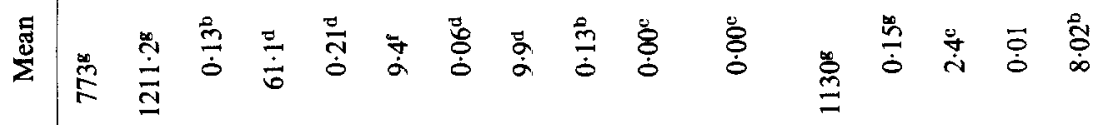

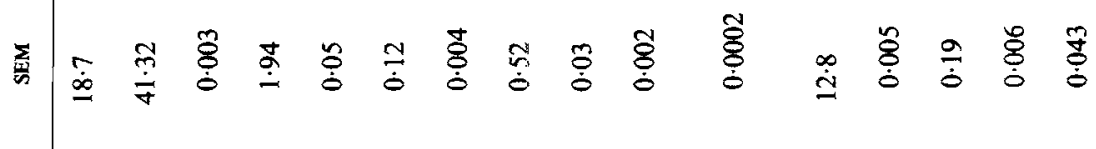

(3)

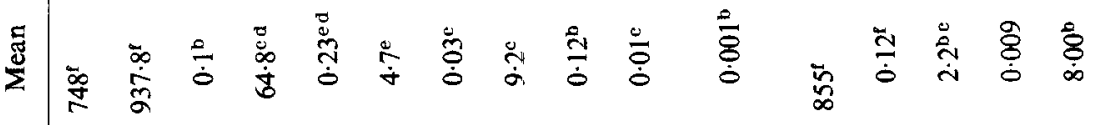

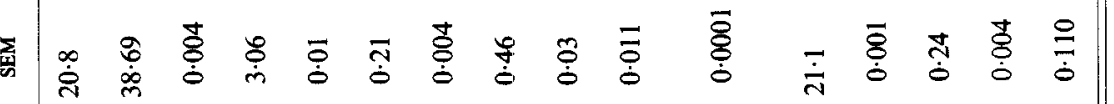

స్

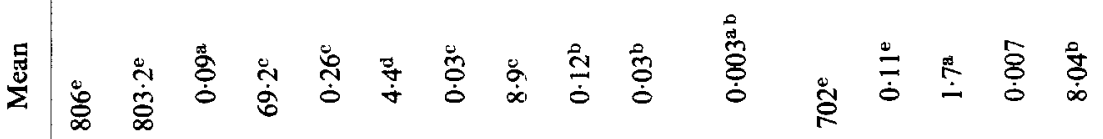

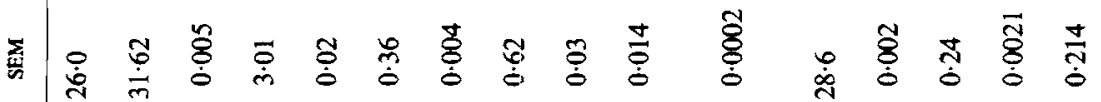

\&

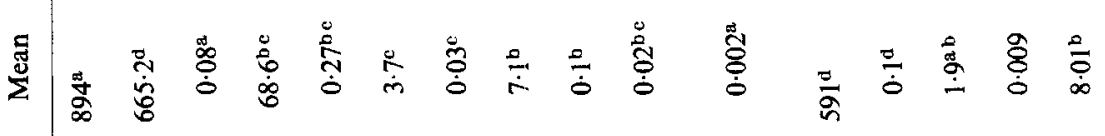

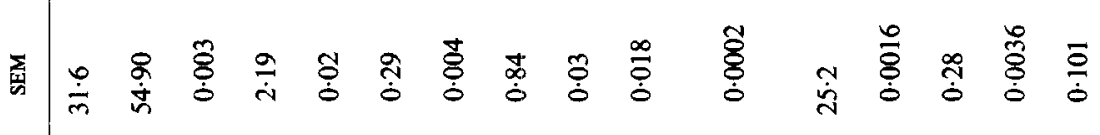

옹

歪

氧

$\stackrel{8}{8}$

ริ)

竧

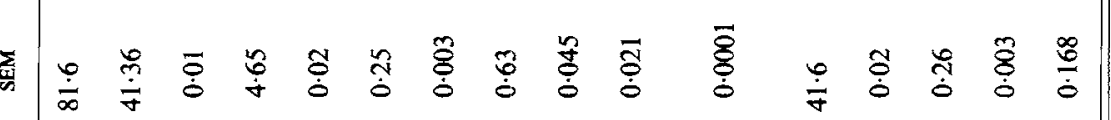

8

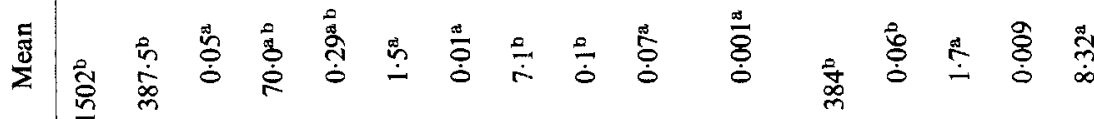

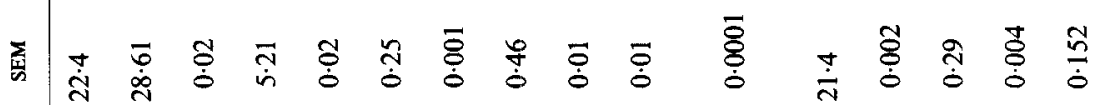

幽

Еั

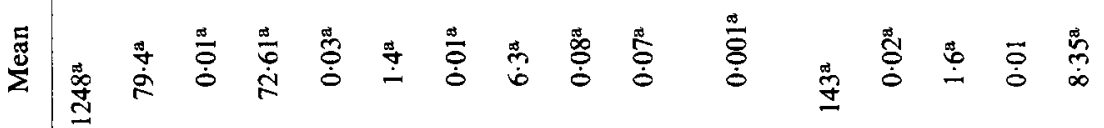

品

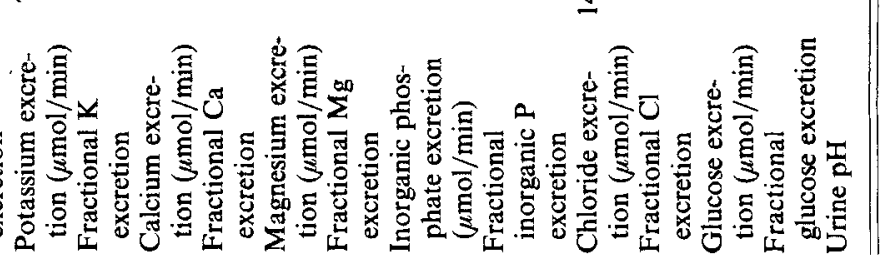


Table 7. The effects of sodium chloride infusion on ad lib. food intakes and digestibility in sheep

(Mean values with their standard errors for eight sheep)

\begin{tabular}{|c|c|c|c|c|}
\hline \multirow[t]{2}{*}{ Salt intake $(\mathrm{mmol} / \mathrm{d}) \ldots$} & \multicolumn{2}{|c|}{0} & \multicolumn{2}{|c|}{2000} \\
\hline & Mean & SEM & Mean & SEM \\
\hline Food intake $(\mathrm{g} / \mathrm{d})$ & 946 & 36 & 908 & 41 \\
\hline Water intake (l/d) & $1 \cdot 16$ & $0 \cdot 294$ & $6 \cdot 38$ & 0.949 \\
\hline \multicolumn{5}{|l|}{ Apparent dige stibility: } \\
\hline Dry matter & 0.61 & $0 \cdot 016$ & $0 \cdot 54^{*}$ & 0.011 \\
\hline Organic matter & 0.52 & 0.010 & $0 \cdot 46^{*}$ & 0.009 \\
\hline Energy & 0.54 & 0.008 & $0.48^{*}$ & 0.009 \\
\hline Nitrogen & 0.61 & 0.024 & $0.49^{*}$ & $0 \cdot 048$ \\
\hline Sodium & $0 \cdot 86$ & 0.043 & 0.91 & 0.038 \\
\hline Potassium & 0.88 & 0.061 & 0.86 & 0.038 \\
\hline Calcium & $0 \cdot 10$ & 0.054 & $0 \cdot 18$ & 0.062 \\
\hline Magnesium & $0 \cdot 20$ & 0.082 & 0.21 & 0.084 \\
\hline Phosphorus & $0 \cdot 14$ & 0.028 & $0 \cdot 10$ & 0.038 \\
\hline \multicolumn{5}{|l|}{ Rumen indices: } \\
\hline Ammonia (mmol/1) & $5 \cdot 6$ & 0.74 & $2 \cdot 8^{*}$ & 0.29 \\
\hline VFA $(\mathrm{mmol} / \mathrm{l})$ & 80 & $3 \cdot 8$ & $71^{*}$ & $4 \cdot 2$ \\
\hline Osmolality (mosmol/kg) & 281 & 6.9 & $328 *$ & $12 \cdot 1$ \\
\hline $\mathrm{pH}$ & 6.44 & 0.058 & $6.71^{*}$ & 0.124 \\
\hline
\end{tabular}

VFA, volatile fatty acids.

* $P<0.01$.

$\mathrm{NH}_{3}$ excretion in urine was not altered by salt intake, except for the highest level of salt infusion, and then it was significantly increased. This was caused by the high excretion of $\mathrm{NH}_{3}$ by one sheep only $(13.8 \mu \mathrm{mol} / \mathrm{min})$.

The concentration of plasma protein remained relatively constant throughout the experiment.

Total $\mathrm{N}$ excretion was constant until $1000 \mathrm{mmol} \mathrm{NaCl} / \mathrm{d}$ were infused and thereafter it decreased with increasing salt intake.

Plasma and urine electrolytes and glucose. Plasma electrolytes and glucose concentrations are shown in Table 5 and their renal excretion in Table 6. Plasma $\mathrm{Na}$ and $\mathrm{Cl}$ levels were virtually unaffected by the treatments, although plasma $\mathrm{Na}$ tended to be lower with the higher infusates. As expected the excretion and fractional excretion of $\mathrm{Na}$ and $\mathrm{Cl}$ increased with increasing salt intake. Plasma $\mathrm{K}$ concentration was unaffected by $\mathrm{NaCl}$ infusions. However, the excretion and fractional excretion of $\mathrm{K}$ were both reduced by the higher salt infusions. Plasma $\mathrm{Ca}$ levels were not altered by the salt infusions, but the excretion and fractional excretion were increased continuously with increasing $\mathrm{NaCl}$ input. Plasma $\mathrm{Mg}$ was significantly lowered by the infusion of 1500 and $2000 \mathrm{mmol} \mathrm{NaCl} / \mathrm{d}$. This corresponded with an increased renal excretion of $\mathrm{Mg}$. Fractional $\mathrm{Mg}$ excretion was somewhat variable and was lowest when no salt was infused. Plasma $P_{j}$ increased with increasing $\mathrm{NaCl}$ input. Urinary $P_{i}$ excretion and fractional excretion were both very low and below detection limits, particularly on the high-salt infusions. Plasma glucose was not affected by the treatments. Excretion of glucose was highest when $2000 \mathrm{mmol} \mathrm{NaCl} / \mathrm{d}$ were infused and urine flow rate was highest (Table 4). Fractional excretion of glucose was not greatly affected. Urine $\mathrm{pH}$ decreased after $1000 \mathrm{mmol} \mathrm{NaCl} / \mathrm{d}$ were infused and remained at this level 
for the remaining infusion periods. Urine osmolality increased when $500 \mathrm{mmol} \mathrm{NaCl} / \mathrm{d}$ was infused, but thereafter decreased with increasing infusion of salt.

Ad lib. feeding. Table 7 shows the values obtained during ad lib. feeding at the two infusion levels, 0 and $2000 \mathrm{mmol} \mathrm{NaCl} / \mathrm{d}$. Food intake was approximately 18 and $13.5 \%$ greater than the restricted level previously fed for the infusion levels 0 and $2000 \mathrm{mmol}$ $\mathrm{NaCl} / \mathrm{d}$ respectively, but the difference in effect between these two infusion levels was not significant.

The apparent digestibility coefficients were similar to the values obtained when these animals were given the limited intake of $800 \mathrm{~g} / \mathrm{d}$ and infused with the same amount of $\mathrm{NaCl}$; thus, compared with the values in Table 3 , the apparent digestibilities were virtually unaffected by the greater food intake. This also applies to the rumen indices shown in Table 2.

\section{DISCUSSION}

The rate that $\mathrm{OM}$ is removed from the rumen is important in limiting the intake of some roughages (Balch \& Campling, 1962). The expected effect of infusing high levels of $\mathrm{NaCl}$ into the rumen was to increase rumen turnover rate and subsequently to stimulate a greater ad lib. food intake. However, increasing osmotic pressure of the gastrointestinal contents has been shown to inhibit food intake in non-ruminants, at least temporarily (Kissileff \& Van Itallie, 1982), and in ruminants (Ternouth, 1968). Kato et al. (1979) provided evidence that the effect is one of ionic composition (i.e. high $\mathrm{Na}^{+}$or $\mathrm{K}^{+}$levels, or both) rather than the actual colligative properties of the rumen ingesta. In the present experiments the increase in rumen osmolality following the administration of salt was substantial, yet ad lib. food intake was unaltered. $\mathrm{NaCl}$ did not decrease food intake and any effect when the sheep were offered food ad lib. was very small and not statistically significant (Table 7). Nevertheless, the osmolality of the rumen fluid may have negated the possible increase in food intake due to increased rumen digesta turnover. The slight increase in rumen volume with the additional salt may also have had some inhibiting effect (Balch \& Campling, 1962).

The increase in rumen liquid outflow with increasing salt input was probably caused mainly by increased water intake (Table 4). Although it was only liquid outflow that was measured, the substantial changes in this index and the decrease in OM digestibility (Table 3) suggest that particulate outflow was also enhanced. As rumen volume was relatively unaltered the changes in concentrations of the microbial metabolites, $\mathrm{NH}_{3}$ and VFA, probably largely reflect changes in their production rates.

The decreasing dry matter digestibility with increasing $\mathrm{NaCl}$ levels was probably a result of two factors. First, the increased rumen outflow decreases the time available for microbial digestion and, second, the higher osmotic pressure of rumen contents reduces the digestion of cellulose (Bergen, 1972; Bennink et al. 1978). The substantial decrease in the digestibility of energy also included a nitrogenous component. Jackson et al. (1971) found that increasing the $\mathrm{Na}$ content of rations from 5 to $25 \mathrm{~g} / \mathrm{kg}$ resulted in a decrease in carcass energy content despite a similar food intake, but digestibility of the food was not measured.

The control animals in the present experiment were included for two reasons: $(a)$ it had been observed in our laboratory on previous occasions that when animals were given low-quality roughages they occasionally had periods of poor appetite and $(b)$ they were used to detect any gross changes in appetite or digestibility associated with environmental factors as the experiment was conducted over a 10 -month period and the experimental area, although under cover, was not temperature controlled or free of draughts. Although the control group was fed once daily, whereas the experimental group was fed twelve times daily, Faichney (1968) showed that feeding sheep at three-hourly intervals or once daily caused no differences in the digestibility of the food. 
In the event no major changes occurred in the indices measured in the control animals indicating that the effects noted in the experimental group were a direct reflection of the salt infusions rather than any concomitant changes in the environment. It has been shown that environmental factors may alter rumen metabolism (Yousri et al. 1977; Christopherson \& Kennedy, 1983).

Ad lib. feeding of the control animals resulted in a $14 \%$ increase in food intake and a decrease in the apparent digestibility of the organic constituents of the food. This is a common observation (Agricultural Research Council, 1980) and is caused mostly by a difference in the rate of passage of digesta (Grovum \& Williams, 1977).

Most studies on the effects of $\mathrm{NaCl}$ on rumen function have been made in animals given concentrate rations, i.e. food high in fermentable protein that would also be highly digestible in the small intestine (Hemsley et al. 1975; Croom et al. 1982). Many studies have also included a mixture of minerals as a supplement, such as artificial saliva by which an additional buffering effect in the rumen is achieved (Harrison et al. 1975; Thomson et al. 1978).

Rogers et al. (1979) gave steers a dominantly roughage ration and infused $26 \mathrm{mmol}$ $\mathrm{NaCl} / \mathrm{kg}$ body-weight, which was approximately equivalent to the $1000 \mathrm{mmol} \mathrm{NaCl} / \mathrm{d}$ infused in the present study, and lowered rumen total VFA by $29 \%$. In the present experiment total VFA concentration was lowered by only $11 \%$ at the highest level of salt infusion.

To maintain maximum microbial protein synthesis, rumen $\mathrm{NH}_{3}-\mathrm{N}$ concentrations must be maintained above $5 \mathrm{mmol} / 1$ (Bondi, 1981). The striking drop in rumen $\mathrm{NH}_{3}$ with increasing salt input was probably caused by an increased proportion of dietary protein escaping degradation in the rumen. However, much of this protein was not available for absorption from the lower gut as shown by the lower digestibility of $\mathrm{N}$. The hydrolytic activity of the rumen microflora on carbohydrate components can be reduced by a lower rumen $\mathrm{NH}_{3}$ level (Wallace, 1979), which also helps to explain the lower energy digestibility values with the high levels of salt.

The return of plasma urea to the rumen is highly dependent on the plasma urea concentration and the presence of readily fermentable carbohydrate in the rumen (Kennedy $\&$ Milligan, 1980). There is also evidence that salivary flow rate is decreased when dietary salt is high (Tomas $\&$ Potter, 1975). The lowered salivary flow rate coupled with the reduced plasma urea level would reduce the return of urea to the rumen by this route.

The renal excretion of urea was lowered by the addition of $\mathrm{NaCl}$. This reduced excretion of urea was the result of greatly decreased plasma concentrations and consequently of reduced filtered loads to the renal tubules, because the fractional excretion of urea actually increased and this may be attributed to the higher urine flow rates, the major determinant of urea clearance (Tang-Liu et al. 1983).

Dixon \& Milligan (1983) measured urea transfer to the rumen, and excretion of urea in the urine, in steers given grass hay and fresh water or $10 \mathrm{~g} \mathrm{NaCl} / \mathrm{l}$ in the drinking water. They found no effects on urea metabolism. However the salt intake from this treatment was only about $20 \mathrm{mmol} / \mathrm{kg}$ body-weight per $\mathrm{d}$. In the present study this level, equivalent to about $750 \mathrm{mmol} / \mathrm{d}$, had little effect on the indices of $\mathrm{N}$ metabolism measured. Previous work from this laboratory has shown that relatively small intraruminal infusions of $\mathrm{NaCl}$ $(500 \mathrm{mmol} / \mathrm{d})$ will reduce the high plasma urea concentrations of urea-loaded sheep by increasing the renal excretion of urea (Godwin \& Williams, 1984).

Ergene \& Pickering (1978) gave sheep a low-protein diet and provided them with fresh or salt water. The animals given the salt water consumed $652 \mathrm{mmol} \mathrm{NaCl} / \mathrm{d}$ and had an increased tubular reabsorption of urea. However, these studies were confounded by the concomitant intravenous infusion of antidiuretic hormone (ADH) to stabilize urine flow rate (Ergene, 1976). 
Valtonen (1979) gave reindeer a low-protein ration and supplemented this with $100-170 \mathrm{mmol} \mathrm{NaCl} / \mathrm{d}$. This level of supplementation decreased the renal tubular load of urea as a result of lowered plasma levels and consequently decreased urea excretion. This effect was similar to that shown in the present study with sheep, but it occurred at a much lower level of salt supplementation, well below that likely to have any profound effect on rumen function. These results may be related to the fact that the reindeer kidney has a much greater proportion of cortical relative to medullary tissue than the sheep and is relatively resistant to ADH (Valtonen \& Eriksson, 1977).

The level of URAL excretion in sheep urine is determined predominately by the amount of microbial protein synthesis in the rumen (Rys et al. 1975), although changes in the level of endogenous allantoin excretion may introduce substantial errors into this supposition (Antoniewicz et al. 1980). In the present study the infusion of $\mathrm{NaCl}$ caused a substantial drop in plasma and urinary excretion of these purine metabolites. The more rapid rumen turnover with salt infusion and the concomitantly lower rumen VFA and $\mathrm{NH}_{3}$ as well as the decreased URAL excretion indicates a lower level of rumen microbial protein synthesis. The increased renal fractional excretion of URAL with salt infusion was greater than unity in most cases which confirms the result of Chesley et al. (1978) that sheep secrete urate by a tubular mechanism. Increased salt intake does not affect uric acid excretion in man (Breslau \& Pak, 1983).

The excretion of $\mathrm{NH}_{3}$ in the urine was low and unaltered in all but one animal by saline infusion. The alkaline $\mathrm{pH}$ of the urine prevents the excretion of appreciable quantities of $\mathrm{NH}_{3}$, as its main function is to buffer secreted acid.

Total $\mathrm{N}$ excretion in the urine followed much the same pattern as urea, as urea was a substantial component. Brook et al. (1964) have suggested that catheterization of the bladder increases protein excretion in the form of mucus secreted from goblet cells along the urethra; therefore the values for total $\mathrm{N}$ excretion may be artificially high.

The lack of change in plasma protein and PCV suggests that blood volume was not altered appreciably, although ECF volume showed a trend toward greater values with increased salt input. This is a typical effect of increased $\mathrm{NaCl}$ intake (Dirks et al. 1976; Godwin \& Williams, 1984). Potter (1961) found that sheep given $13 \mathrm{~g} \mathrm{NaCl} / 1$ as drinking water, through which they voluntarily consumed $1000 \mathrm{mmol} \mathrm{NaCl} / \mathrm{d}$ for prolonged periods, have an increased GFR and a reduced ERPF resulting in a greater renal filtration fraction. In the present study, with this level of salt intake there was no change in GFR, ERPF or filtration fraction. However, Potter's (1961) animals were drenched with 1 litre of their drinking water just before the functional measurements.

Chronic salt loading results in an increased ERPF and ECF and, due to a reduced sensitivity of the tubulo-glomerular feedback mechanism in the kidney, increased GFR (Haberle \& Davis, 1982). The enhanced ERPF may be due to an increase in systemic blood pressure, although Potter (1972) reports that the blood pressure of sheep is somewhat refractory to dietary $\mathrm{NaCl}$.

The osmolality of urine samples showed a typical response to osmotic diuresis, i.e. a decrease with increasing salt intake.

The striking increase in $\mathrm{Ca}$ excretion with $\mathrm{NaCl}$ infusions is of interest as the digestibility of $\mathrm{Ca}$ did not follow the renal excretory pattern. The renal fractional excretion of $\mathrm{Ca}$ also increased more than five-fold. ECF volume expansion enhances Ca excretion (Massry et al. 1967). Recently Goulding \& Campbell (1983) have shown that dietary $\mathrm{NaCl}$ enhances bone loss and $\mathrm{Ca}$ excretion in rats, thus it is possible that in sheep high $\mathrm{NaCl}$ intake causes bone $\mathrm{Ca}$ release. The renal clearances of $\mathrm{Na}$ and diffusible $\mathrm{Ca}$ are closely related (Massry et al. 1968) and $\mathrm{Na}$ is required for active $\mathrm{Ca}$ reabsorption (Borle, 1982). Na-induced hypercalciuria is accompanied by increased 1,25-dihydroxyvitamin $D_{3}$ synthesis and enhanced $\mathrm{Ca}$ absorption from the intestine of man (Breslau et al. 1982). In cattle, increasing 
the $\mathrm{Na}$ concentration of the rumen, omasum and, abomasum increases the absorption of Ca from these compartments (Timet et al. 1978). In the present study there was an increase in $\mathrm{Ca}$ digestibility until $1000 \mathrm{mmol} \mathrm{NaCl} / \mathrm{d}$ were infused and thereafter it decreased slightly. This suggests that the Na-effect described by Timet et al. (1978) may have occurred up to this level and at higher $\mathrm{Na}$ levels the changes in the rate of passage modify the overall effect. $\mathrm{Ca}$ is mostly absorbed from the proximal small intestine (Phillipson \& Storry, 1965), where $\mathrm{Na}$ is required for its optimal absorption (Martin \& De Luca, 1969).

$\mathrm{Mg}$ absorption showed a similar pattern to that of Ca absorption, even though $\mathrm{Mg}$ is absorbed mostly from the rumen (Tomas \& Potter, 1976). Increasing the $\mathrm{Na}^{+}: \mathrm{K}^{+}$value of rumen contents increases the net absorption of $\mathrm{Mg}$ from an isolated sheep rumen (Care et al. 1981). Again this effect may be limited by an increased rate of passage of digesta at higher $\mathrm{NaCl}$ infusion rates. The increased excretion of $\mathrm{Mg}$ with the high levels of $\mathrm{NaCl}$ was probably the cause of the lowered plasma $\mathrm{Mg}$ levels. Increasing the water intake of sheep by intraruminal infusion causes increased urinary losses of both $\mathrm{Mg}$ and $\mathrm{Ca}$ (Suttle \& Field, 1967).

The decrease found in $\mathrm{P}_{\mathrm{i}}$ excretion may well be an analytical artefact as many of the urine samples, particularly the more dilute samples from salt-infused animals, were below detection limits for $P_{i}$. The urine of sheep given roughage rations normally contains very little $\mathrm{P}_{\mathrm{i}}$ (Tomas, 1974; Godwin \& Williams, 1982) with the major route of excretion being via saliva and hence in the faeces (Tomas, 1974). The increase in the plasma level of $P_{i}$, although substantial, was still below the threshold for $P_{i}$ excretion (Watson, 1933) and hence the very low excretion rates. The increase in plasma $P_{i}$ may be related to a reduced salivary flow, caused by the salt infusion (Tomas \& Potter, 1975), or possibly by parathyroid hormone stimulation of osteoclastic activity in response to salt loading (Breslau et al. 1982; Goulding \& Campbell, 1983). Parathyroid hormone is thought not to affect $P_{i}$ excretion in sheep when plasma levels are below the threshold described by Watson (1933) (Clark et al. 1975).

Glucose excretion by ruminants is considerably higher than that of most other species (Macfarlane, 1976). The high salt infusion levels increased this excretion, probably simply as a result of diuretic wash out, although glucose excretion has been negatively related to plasma $\mathrm{pH}$ and urine $\mathrm{pH}$ (I. R. Godwin and G. A. Chaffey, unpublished results). In the present study, urine $\mathrm{pH}$ was decreased slightly by the salt infusion. ECF volume expansion also results in a shunting of blood from the medullary to the cortical areas of the kidney (Knox \& Haas, 1982) which leads to an increased production of glucose by gluconeogenesis (McIntosh et al. 1973) which may possibly diffuse into the tubular fluid.

Under natural conditions salt may enter the animal in either the food or in drinking water. Addition of salt via these two sources may well have different effects, depending on the concentrations of salt and the frequency of feeding and watering (Wilson, 1966 b). Continuous infusion of salt through a rumen fistula and free access to fresh water as used in the present study bypasses any effects on palatability and also reduces the likelihood of a rapid and large increase in rumen osmolality. The turnover of rumen contents occurs continuously and the animal can exercise no control over the amount and timing of its salt intake with continuous infusion. Drenching lambs with salt $(34 \mathrm{mmol} / \mathrm{kg}$ body-weight per d) once daily causes little effect on growth rate (Hamilton et al. 1983). This appears to be due to a rapid wash out of rumen contents shortly after drenching, and a quick return to normal rumen function and eating behaviour (J. A. Hamilton, personal communication). Much of the literature on salt effects in sheep are confounded by differences in presentation of the salt and hence probable differences in gut function as a result. Further studies comparing the effects of these different modes of presentation are warranted.

In conclusion, $750 \mathrm{mmol} \mathrm{NaCl} / \mathrm{d}$ may be infused intraruminally into sheep given 
low-protein roughages with little effect except for increased water intake and excretion. Higher salt inputs cause an increased rumen turnover rate and a consequent lowering of dry matter digestibility and particularly $\mathrm{N}$ digestibility. This results in decreased rumen $\mathrm{NH}_{3}$ and plasma urea levels and a decreased urea excretion rate. The kidneys also show an enhanced excretion of filtered urea and $\mathrm{Ca}$. The previously described effects would almost certainly be detrimental to the production of animal protein.

The authors thank the Australian Wool Corporation for financial support and $\mathrm{Mr}$ G. Chaffey and Ms B. Fraser for their valuable technical assistance.

\section{REFEREN CES}

Agricultural Research Council (1980). The Nutrient Requirements of Ruminant Livestock. Farnham Royal, Slough: Commonwealth Agricultural Bureaux.

Antoniewicz, A. M., Heinemunn, W. W. \& Hanks, E. M. (1980). Journal of Agricultural Science, Cambridge 95 , 395-400.

Bacon, J. S. D. \& Bell, D. J. (1948). Biochemical Journal 42, 397-405.

Balch, C. C. \& Campling, R. C. (1962). Nutrition Abstracts and Reviews 32, 669-686.

Bennink, M. R., Tyler, T. R., Ward, G. M. \& Johnson, D. E. (1978). Journal of Dairy Science 61, 315-323.

Bergen, W. G. (1972). Journal of Animal Science 34, 1054-1060

Bondi, A. (1981). Nutrition Reports International 35, 993-1004.

Borle, A. B. (1982). Journal of Membrane Biology 66, 183-191.

Breslau, N. A., McGuire, J. L., Zerwekh, J. E. \& Pak, C. Y. C. (1982). Journal of Clinical Endocrinology and Metabolism 55, 369-373.

Breslau, N. A. \& Pak, C. Y. C. (1983). Journal of Urology 129, 531-532.

Brook, A. H., Waites, G. M. H. \& Stacy, B. D. (1964). Quarterly Journal of Experimental Physiology 49, 297-300.

Care, A. D., Farrer, A. R. \& Pickard, D. W. (1981). Journal of Physiology London 325, 55P-56P.

Chesley, L. C., Holm, L. W., Parker, H. R. \& Assali, N. S. (1978). Proceedings of the Society of Experimental Biology and Medicine 159, 386-389.

Christopherson, R. J. \& Kennedy, P. M. (1983). Canadian Journal of Animal Science 63, 477-496.

Clark, R. C., French, T. J., Beal, A. M., Cross, R. B. \& Budtz-Olsen, O. E. (1975). Quarterly Journal of Experimental Physiology 60, 95-106.

Cresser, M. S. \& Parsons, J. W. (1979). Analytica Chimica Acta 199, 431-436.

Croom, W. J., Harvey, R. W., Linnend, A. C. \& Froetschel, M. (1982). Canadian Journal of Animal Science 62, 217-227.

Dirks, J. H., Seely, J. F. \& Levy, M. (1976). In The Kidney, pp. 495-552 [B. M. Brennen and R. C. Rector, editors]. Philadelphia: Saunders.

Dixon, R. M. \& Milligan, L. P. (1983). Canadian Journal of Animal Science 63, 149-154.

Ergene, N. (1976). Studies on urea excretion in sheep. PhD Thesis, University of Liverpool.

Ergene, N. \& Pickering, E. C. (1978). Quarterly Journal of Experimental Physiology 63, 67-76.

Faichney, G. J. (1968). Australian Journal of Agricultural Research 19, 813-819.

Faichney, G. J. (1975). In Digestion and Metabolism in the Ruminant, pp. 277-291 [I. W. McDonald and A. C. I. Warner, editors]. Armidale, NSW: University of New England Publishing Unit.

Godwin, I. R. \& Williams, V. J. (1982). Australian Journal of Agricultural Research 33, 843-855.

Godwin, I. R. \& Williams, V. J. (1983). Proceedings of the Nutrition Society of Australia 8, 190.

Godwin, I. R. \& Williams, V. J. (1984). Quarterly Journal of Experimental Physiology 69, 49-59.

Goulding, A. \& Campbell, D. (1983). Journal of Nutrition 113, 1409-1414.

Grovum, W. L. \& Williams, V. J. (1977). British Journal of Nutrition 38, 425-436.

Haberle, D. A. \& Davis, J. M. (1982). Klinische Wochenschrift 60, 1245-1248.

Hamilton, J. A., Burton, M. A. \& Webster, M. E. D. (1983). Proceedings of the XXIX Congress of the International Union of Physiological Sciences, Sydney, Australia, vol. 15, 407.

Harrison, D. G., Beever, D. E., Thomson, D. J. \& Osbourn, D. F. (1975). Journal of Agricultural Science, Cambridge 85, 93-101.

Hemsley, J. A. (1975). Australian Journal of Agricultural Research 26, 709-714.

Hemsley, J. A., Hogan, J. P. \& Weston, R. H. (1975). Australian Journal of Agricultural Research 26, 715-727.

Houpt, T. R. \& Houpt, K. A. (1968). American Journal of Physiology 214, 1296-1303.

Jackson, H. M., Kromann, R. P. \& Ray, E. E. (1971). Journal of Animal Science 33, 872-877.

Kato, S., Sasaki, Y. \& Tsuda, T. (1979). Annales Recherche Veterinaire 10, 229-230.

Kennedy, P. M. \& Milligan, L. P. (1980). Canadian Journal of Animal Sciences 60, 205-221.

Kissileff, H. R. \& Van Itallie, T. B. (1982). Annual Review of Nutrition 2, 371-418. 
Knox, F. G. \& Haas, J. A. (1982). Reviews of Physiology, Biochemistry \& Pharmacology 92, 75-113.

Macfarlane, W. V. (1976). In Veterinary Physiology, pp. 461-539 [J. W. Phillis editor]. Bristol: Wright-Scientechnica.

McIntosh, G. H., Filsell, O. H. \& Jarrett, I. G. (1973). Australian Journal of Biological Sciences 26, 1389-1394.

Martin, D. L. \& De Luca, H. F. (1969). American Journal of Physiology 216, 1351-1359.

Massry, S. G., Coburn, J. W., Chapman, L. W. \& Kleeman, C. R. (1967). American Journal of Physiology 213 , 1218-1224.

Massry, S. G., Coburn, J. W., Chapman, L. W. \& Kleeman, C. R. (1968). American Journal of Physiology 214, 1403-1409.

Nicol, G. R. \& Corbett, J. L. (1971). Laboratory Practice 20, 727-728.

Phillipson, A. T. \& Storry, J. E. (1965). Journal of Physiology, London 181, 130-150.

Potter, B. J. (1961). Australian Journal of Agricultural Research 12, 440-445.

Potter, B. J. (1972). Australian Journal of Experimental Biology and Medical Science 50, 387-389.

Poulsen, H. L., Jensen, H. E. \& Parving, H. (1977). Scandinavian Journal of Clinical \& Laboratory Investigation 37, 69l-696.

Rabinowitz, L., Wegienke, E. A., Gunther, R. A. \& Warren, D. T. (1971). Nephron 8, 313-316.

Rogers, J. A., Marks, B. C., Davis, C. L. \& Clark, J. H. (1979). Journal of Dairy Science 62, 1599-1605.

Rys, R., Antoniewicz, A. \& Maciejewicz, J. (1975). Tracer Studies on Non-protein Nitrogen for Ruminants, vol. 2, pp. 95-98. Vienna: International Atomic Energy Agency.

Smith, H. W., Finkelstein, L., Aliminosa, B., Crawford, B. \& Craber, M. (1945). Journal of Clinical Investigation 24, 388-404.

Somers, M. (1961). Australian Journal of Experimental Biology and Medical Science 39, 111-122.

Suttle, N. F. \& Field, A. C. (1967). British Journal of Nutrition 21, 819-831.

Tang-Liu, D. D.-S., Tozer, T. N. \& Riegelman, S. (1983). Journal of Pharmaceutical Sciences 72, $154-158$.

Ternouth, J. H. (1968). Proceedings of the Australian Society of Animal Production 7, 369-375.

Thomson, D. J., Beever, D. E., Latham, M. J., Sharpe, M. E. \& Terry, R. A. (1978). Journal of Agricultural Science, Cambridge 91, 1-7.

Timet, D., Emanovic, D., Herak, M., Kraljevic, P.\& Mitin, V. (1978). Veterinarski Arkiv 48, S37-S38.

Tomas, F. M. (1974). Australian Journal of Agricultural Research 25, 485-493.

Tomas, F. M. \& Potter, B. J. (1975). Australian Journal of Agricultural Research 26, 585-598.

Tomas, F. M. \& Potter, B. J. (1976). British Journal of Nutrition 36, 37-45.

Valtonen, M. (1979). Journal of the Scientific Agricultural Society of Finland 51, 381-419.

Valtonen, M. \& Eriksson, L. (1977). Acta Physiologica Scandinavica 100, 340-346.

Wallace, R. J. (1979). Journal of Applied Bacteriology 47, 443-455.

Watson, R. H. (1933). Australian Journal of Experimental Biology 11, 197-207.

Wilson, A. D. (1966a). Australian Journal of Agricultural Research 17, 155-163.

Wilson, A. D. (1966 b). Australian Journal of Agricultural Research 17, 503-514.

Yousri, R. M., Abou Akkada, A. R. \& Abou Raya, A. K. (1977). World Review of Animal Production 13, 51-56. 